\title{
Coulisses
}

Revue de théâtre

40 | Hiver 2010

Jeux de rappels chez Marivaux

\section{Le théâtre à la saline royale d'Arc et Senans, été 2009}

Tchékhov, La Cerisaie

\section{Marianne Camus}

\section{OpenEdition}

\section{Journals}

Édition électronique

URL : https://journals.openedition.org/coulisses/647

DOI : $10.4000 /$ coulisses. 647

ISSN : 2546-9460

\section{Éditeur}

Presses universitaires de Franche-Comté

Édition imprimée

Date de publication : 1 janvier 2010

Pagination : 19-20

ISBN : 978-2-84867-283-0

ISSN : $1150-594 X$

\section{Référence électronique}

Marianne Camus, «Le théâtre à la saline royale d'Arc et Senans, été 2009 », Coulisses [En ligne], 40

Hiver 2010, mis en ligne le 30 novembre 2016, consulté le 29 décembre 2022. URL : http://

journals.openedition.org/coulisses/647 ; DOI : https://doi.org/10.4000/coulisses.647

Ce document a été généré automatiquement le 29 décembre 2022.

Tous droits réservés 


\title{
Le théâtre à la saline royale d'Arc et Senans, été 2009
}

\author{
Tchékhov, La Cerisaie
}

Marianne Camus

\section{RÉFÉRENCE}

Tchékhov, La Cerisaie

Mise en scène : Guillaume Dujardin

1 Les personnages traversent à grandes enjambées l'immense espace de la Saline d'Arc et Senans, espace si vaste qu'ils doivent être équipés de micros d'une efficacité parfois aléatoire. Il n'est pas sûr que cet étirement de l'espace serve vraiment la poésie et surtout la tension qui sous-tendent la nonchalance apparente de La Cerisaie. Sauf quand il s'agit de la scène du bal où la démesure de l'endroit souligne la déliquescence d'une classe dansant sur sa tombe.

2 Mais il y a le moment magique de la scène jouée en extérieur sur la pelouse à la nuit tombante où, entourés par les bâtiments à la fois sévères et élégants de Claude-Nicolas Ledoux, les spectateurs sont transportés dans un autre monde, un monde où l'on savait encore jouir de l'instant. Et il y a les acteurs qui réussissent à transcender les difficultés pratiques et à faire passer le texte, et le sous texte de Tchékhov. Lopakhine, déchiré entre son arrivisme d'homme du futur et son attachement à ses maîtres ancestraux est joué avec force et conviction. De même, le mélange de pathétique et de ridicule qui caractérise les personnages de Lioubov Andréevna et de Gaev est lui aussi rendu sans complaisance mais sans exagération. Les autres personnages, chacun pris et enfermé dans son rêve ou son obsession, sont fidèles au monde tchékhovien en même temps qu'ils révèlent l'actualité toujours de mise du dramaturge.

Guillaume Dujardin signe ici une mise en scène inventive et attachante de cette pièce douce-amère sur l'inadaptabilité de l'être humain - ou serait-ce sur sa capacité à s'adapter de manière égoïste et destructrice? Destructrice pour les cerisaies 
transformées en lotissements de maisons de vacances, mais surtout destructrice de l'être humain lui-même, qu'il finisse arraché au passé qui l'a construit ou abandonné comme le vieux Firs, seul dans la maison non seulement close mais verrouillée. Et à ce moment-là, l'espace fonctionne parfaitement, une image du désert de toutes ces vies utilisées et jetées sans un regard, sans une pensée.

INDEX

oeuvrecitee Cerisaie (La) 